Researchers outside government point out that if the DHS is simply funneling the funds back to the NIH, then there is no need to give the new department control over the funding. Testifying before Congress in a 9 July hearing on the DHS, Gail Cassell, past president of the American Society for Microbiology, argued, "a scientific health agency ... rather than the non-scientific, non-public health DHS, should have the principal authority for developing and prioritizing scientific and health-related programs."

Embarrassingly, just one week after the Bush administration submitted its proposal to Congress, a blue-ribbon panel convened by the National Academy of Sciences (NAS) issued detailed recommendations on research priorities to combat terrorism. Some of the NAS report's suggestions have found sympathetic ears in Congress, and many researchers are hoping for substantial changes in the administration's proposal before the DHS is established on 1 January 2003.

Cassell and some members of Congress favor an approach similar to the one outlined in the NAS report, in which an Assistant Secretary within the DHS would help coordinate relevant antiterrorism research, but prioritization and funding authority would remain with the individual research agencies. If bioterrorism research funding remains with the NIH and CDC rather than moving through the new department, the DHS will have a total research portfolio of only $\$ 500$ million.

There is also concern that merging basic research programs into a defense agency could hinder academic openness. For example, the administration's proposal calls for exempting the DHS from laws that allow public scrutiny of government agencies. Barbara Hatch Rosenberg, a bioweapons expert at the State University of New York, agrees that there is the chance "of secrecy being imposed. If there's a lot of money to be gained, there's a possibility that researchers will agree to keep results secret rather than publish."

Rosenberg asserts that insulating biodefense research from public view, combined with the planned construction and staffing of several new highlevel biological containment facilities, could actually increase the chance of bioterrorism.

Alan Dove, Philadelphia

\title{
SCNT ban dropped from Congress...
}

Pro-science lobbyists are claiming victory in the US. A well-organized campaign by patients' groups and drug and biotechnology firms appears to have thwarted prospects for legislation to ban all forms of human somatic-cell nuclear transfer (SCNT) in the Senate.

The House of Representatives approved a total ban on all forms of SCNT last July, and the Senate was believed to be close behind with its own sweeping prohibition, based on a bill authored by Senator Sam Brownback (R-Kansas). The bill had to be stopped before it could reach the desk of President Bush, who had vowed to sign it.

The campaign was a classic lesson in how to change the language-and thus, the nature-of the national debate. And it worked. Supporters, realizing they fell far short of the needed votes, have decided to halt efforts to bring the legislation to the floor of the Senate for discussion, and Senate Leader Tom Daschle (D-South Dakota), said it was unlikely to be revived.

Opponents shunned the word "cloning," opting instead for such terms embraced by scientists as "somatic-cell nuclear transfer," "nuclear transplantation," or "regenerative medicine." And, similarly wary of the term "embryo," they began to argue that an embryo created through cloning is not the same as one made through the traditional union of sperm and egg. Even those in favor of the legislation agreed that their opponents' strategy was effective. David Prentice, a professor of life sciences at Indiana State University, a cloning foe who had been advising anticloning senators says, "Changing the terms for the procedure itself confused the public and the policymakers, and the only message many heard was "potential cures."

"The senate cloning ban is dead," Art Caplan, director of the University of Pennsylvania center for bioethics, told Nature Medicine. He attributes this to the "inability of proponents of the ban to mount a credible 'secular' case against therapeutic cloning." However, lobbyist Dan Perry, executive director of the Alliance for Aging Research, warned that the battle was still not over: Brownback can still try to attach parts of his ban to other legislation, thus potentially dooming other bills most senators want to pass (see below).

Senate Republicans also lost two key anti-abortion allies, Orrin Hatch (R-Utah) and Strom Thurmond (R-South Carolina), who threw their support behind an alternative measure sponsored by Senator Dianne Feinstein, (D-California), that would ban reproductive cloning but allow it for therapeutic purposes.

Marlene Cimons, Washington, D.C.

\section{...but linked to patent law}

Within days of the vote to ban somatic-cell nuclear transfer (SCNT) being defeated, Senator Sam Brownback tried another tack, proposing instead to ban patents on SCNTderived material. Many believe the new proposal is simply an alternate route to a cloning ban.

"You're taking away the economic incentive for people to do the research," says Michael J. Werner, vice president for bioethics with the Biotechnology Industry Association. "The biotechnology industry relies on intellectual property rights. If that's going to be denied you're going to see a drying up of this research."

For years, scientific and environmental groups concerned about the long-term implications of bioengineering have argued that life forms are community property and should remain in the public domain. Legally, that has been a losing argument since 1980, when the US Supreme Court ruled that human-made microorganisms are patentable. That policy was extended to bioengineered plants and animals.
However, the US Constitution precludes patents on humans. Arti K. Rai, a law professor at the University of Pennsylvania specializing in biotechnology and patent law, says that Brownback is relying on a blurring of these distinctions with regard to an engineered embryo not created for reproductive purposes.

Brownback insists the patent debate is separate from the effort to ban cloning. The issue is whether "...we as a government will allow a person, a human in any stage or age of its development and growth, to be patented," he told fellow lawmakers.

Meanwhile, a White House panel has called for a short-term moratorium on SCNT work. A report issued from the President's Council on Bioethics after the Senate debate to ban SCNT stated that a 6month ban would "show respect for the deep moral concerns of the large number of Americans." Congress, however, is not expected to revisit the issue this session.

Tinker Ready, Boston 